\title{
Effect of seaweed and cholesterol-enriched diets on postprandial lipoproteinaemia in rats
}

\author{
Aránzazu Bocanegra ${ }^{1}$, Sara Bastida ${ }^{1}$, Juana Benedí ${ }^{2}$, Meritxell Nus ${ }^{1}$, Jose M. Sánchez-Montero ${ }^{3}$ \\ and Francisco J. Sánchez-Muniz ${ }^{1 *}$ \\ ${ }^{1}$ Departamento de Nutrición y Bromatología I (Nutrición), Facultad de Farmacia, Universidad Complutense de Madrid, \\ 28040 Madrid, Spain \\ ${ }^{2}$ Departamento de Farmacología, Facultad de Farmacia, Universidad Complutense de Madrid, 28040 Madrid, Spain \\ ${ }^{3}$ Departamento de Química Orgánica y Farmacéutica, Facultad de Farmacia, Universidad Complutense de Madrid, \\ 28040 Madrid, Spain
}

(Received 18 March 2009 - Revised 5 June 2009 - Accepted 23 June 2009 - First published online 4 September 2009)

High postprandial lipaemia increases cardiovascular risk. Algae consumption may affect postprandial lipoproteinaemia. The effects of dietary alga and cholesterol supplementation on postprandial lipaemia and lipoproteinaemia and arylesterase (AE) activity in growing male Wistar rats were tested in the present study. Six groups of ten rats were fed a casein-based diet for 3 weeks. Three of the diets contained $2.4 \%$ cholesterol-raising agent (Chol), while the other three did not (NChol). Seven percentage of the control diets (NChol-C and Chol-C) consisted of a cellulose-wheat starch mix (35:65), while the Nori alga diets (NChol-N and Chol-N) and Konbu diets (NChol-K and Chol-K) contained $7 \%$ of each respective freeze-dried alga. Postprandial plasma was obtained after a $3 \mathrm{~h}$ diet withdrawal. Supplementary cholesterol and alga type significantly affected (at least $P<0.05$ ) the cholesterol, TAG, phospholipid and protein contents of the various lipoprotein fractions. AE enzyme activity increased $(P<0 \cdot 05)$ in NChol rats given Nori and Konbu diets. NChol-K, but not NChol-N, rats displayed higher $(P<0 \cdot 05)$ plasma cholesterol, TAG and phospholipid levels than NChol-C animals. NChol-K rats presented higher TAG, phospholipid, protein and lipoprotein mass values than their NChol-C counterparts. Inclusion of algae in Chol diets decreased $(P<0.001)$ the postprandial hypertriacylglycerolaemia. The Chol-N diet affected most lipoprotein fraction contents. Chol-N rats had lower postprandial cholesterolaemia and a better lipoprotein profile (fewer LDL and a tendency toward more HDL and fewer cholesterol-enriched VLDL) than Chol-K rats, suggesting that Nori is the alga of choice in dietary treatment of hypercholesterolaemia.

Seaweeds: Plasma and lipoprotein lipids: Hypercholesterolaemia: Postprandial lipoproteinaemia: Arylesterase activity

Marine algae have traditionally been consumed in great quantity in Asia and to a lesser degree in other parts of the world $^{(1)}$. In recent years, these marine vegetables have gained popularity in Western countries due to the introduction of authentic Asian cuisine and their use in vegetarian diets. Common edible algae belong to the genera Porphyra and Laminaria $^{(2-4)}$. Edible seaweeds are rich in non-digestible polysaccharides (fibre), minerals and vitamins, and contain relatively high percentages of certain PUFA ${ }^{(5)}$.

Although consensus has not yet been reached, various authors have reported that seaweeds, their water-soluble fraction or isolated algal polysaccharides exhibit hypocholesterolaemic $^{(5,6)}$ effects in experimental animals. However, data regarding their antioxidant effects are controversial ${ }^{(5,7)}$. Several studies have shown that atherosclerosis risk is not only attributed to total serum cholesterol, but also to the distribution of cholesterol among the different lipoproteins ${ }^{(8,9)}$. Moreover, postprandial lipaemia/lipoproteinaemia has been considered a risk factor for $\mathrm{CHD}^{(10)}$. Dietary fibre that contains viscous polysaccharides can affect digestion, absorption and subsequent metabolism of dietary fat and cholesterol by slowing gastric emptying ${ }^{(7,11)}$, and may thus modify postprandial lipaemia ${ }^{(12)}$. Various soluble fibres delay the absorption of dietary fat in the rat ${ }^{(13)}$. Nonetheless, test results are controversial because pre-adaptation of rats to cellulose, oat bran or psyllium did not alter postprandial lipid levels when a fibre-free, high fat test meal was fed ${ }^{(14)}$. According to Olson \& Schneeman ${ }^{(11)}$, plasma TAG levels were higher in a group of rats on an oat bran diet than in a cellulose diet group after $4.5 \mathrm{~h}$. To the best of our knowledge, the effect of consumption of these algae on postprandial lipaemia in rats fed cholesterol-enriched diets has not been studied to date.

Arylesterase (AE) activity is one of the three major activities of the paraoxonase 1 enzyme ${ }^{(15,16)}$, which is bound to the HDL particle and inhibits lipid peroxide generation in $\mathrm{LDL}^{(16)}$. AE activity in serum or plasma is inversely related

Abbreviations: AE, arylesterase; Chol-C, cholesterol-enriched control diet; Chol-K, cholesterol-enriched Konbu diet; Chol-N, cholesterol-enriched Nori diet;

NChol-C, non-Chol-C; NChol-K, non-Chol-K; NChol-N, non-Chol-N.

* Corresponding author: Francisco J. Sánchez-Muniz, fax +34 9139418 10, email frasan@farm.ucm.es 
to $\mathrm{CHD}^{(17)}$. Modifications of $\mathrm{AE}$ activity have been observed under different dietary conditions ${ }^{(18)}$. Antioxidants such as certain pomegranate polyphenols have been found to increase or maintain high AE activity levels ${ }^{(19)}$. Consumption of wonderful variety pomegranate juice and extract increases paraoxonase 1 association with HDL and stimulates its catalytic activity in diabetic patients ${ }^{(19)}$. To our knowledge, the effect of alga consumption on AE activity has not yet been tested.

The hypothesis of the present paper is that the effect of different types of algae on postprandial lipaemia, lipoproteinaemia and $\mathrm{AE}$ activity of rats varies between rats fed cholesterol-enriched diets and those given noncholesterol-enriched diets. Thus, the aim of the present study was to compare the effects of dietary seaweed (Konbu or Nori) supplements on postprandial lipaemia and lipoproteinaemia and $\mathrm{AE}$ activity in growing male Wistar rats fed cholesterol- or non-cholesterol-enriched diets.

\section{Materials and methods}

\section{Materials}

The edible red and brown marine seaweeds Nori (Porphyra tenera, class Rhodophyceae) and Konbu (Laminaria digitata, class Phaeophyceae) were obtained from a local supplier (Algamar C.B., Redondela, Pontevedra, Spain). These seaweeds were freeze-dried and grounded, using a cyclotic mill (Tecator 1093; Foss Tecator, Hoeganaes, Sweden), to a particle size of $<1.0 \mathrm{~mm}$ before use. The composition of the seaweeds employed in the present study has been reported previously ${ }^{(20)}$. Both algae contain a matrix of soluble, insoluble and total dietary fibre (g/100 g dry weight): 9.15; $26.98 ; 36 \cdot 12$, respectively, in Konbu and 14.56; 19.22; 33.78 , respectively, in Nori ${ }^{(20)}$. Other compounds $(\mathrm{g} / 100 \mathrm{~g}$ dry weight) found in Konbu and Nori included protein (10.7 and 28.3 , respectively) and fat (1.83 and 1.64 , respectively). Although the fat content of seaweeds is low, these vegetables have a high proportion of SFA and unsaturated fatty acids ${ }^{(21)}$. In fact, $20-50 \%$ of their total fatty acid content consists of $n-3$ fatty acids ${ }^{(22)}$. Both algae are rich in minerals, but Nori contains higher amounts of $\mathrm{Fe}, \mathrm{Mn}, \mathrm{Cu}$ and $\mathrm{Na}$, while $\mathrm{Konbu}$ is richer in $\mathrm{Ca}$ and $\mathrm{K}$ and has higher $\mathrm{Zn} / \mathrm{Cu}$ ratio ${ }^{(5)}$. Konbu also contains higher amounts of some heavy metals such as $\operatorname{arsenic}^{(5)}$. Moreover, algae contain different antioxidant compounds such as catechins and phlorotannins ${ }^{(23,24)}$, whose antioxidant activity is similar to that of $\alpha$-tocopherol ${ }^{(25)}$.

\section{Diet preparation and experimental design}

Ninety-three percentage of each of the three homogeneous, experimental and semi-synthetic diets without supplementary cholesterol consisted of a commercial rodent diet (AIN-93M Purified Rodent Diet; DYETS, Inc., Bethlehem, Pennsylvania PA, USA), while the remaining $7 \%$ consisted of a cellulosewheat starch mix $(35: 65$, w/w; non-cholesterol-enriched control diet, NChol-C) or $7 \%$ freeze-dried algae (non-cholesterol-enriched Nori diet, NChol-N, or non-cholesterol-enriched Konbu diet, NChol-K). The three cholesterol-enriched diets (Chol-C, Chol-N and Chol-K) were identical to those previously described, but with $2 \%$ cholesterol and $0.4 \% \mathrm{Na}$ cholate instead of $2.4 \%$ maize starch (Table 1 ).

Table 1. Composition of the control, Nori and Konbu experimental diets with and without supplementary cholesterol

\begin{tabular}{|c|c|c|c|c|}
\hline \multirow{2}{*}{$\begin{array}{l}93 \% \text { Diet AIN-93M + 7\% } \\
\text { supplement }(\mathrm{g} / \mathrm{kg})\end{array}$} & \multicolumn{2}{|c|}{$\begin{array}{c}\text { Without supplementary } \\
\text { cholesterol }\end{array}$} & \multicolumn{2}{|c|}{$\begin{array}{l}\text { With supplementary } \\
\text { cholesterol }\end{array}$} \\
\hline & Control & Algae & Control & Algae \\
\hline Casein & $130 \cdot 2$ & $130 \cdot 2$ & $130 \cdot 2$ & $130 \cdot 2$ \\
\hline Maize starch & 433.093 & 433.093 & $410 \cdot 715$ & $410 \cdot 715$ \\
\hline Dyetrose $^{*}$ & $144 \cdot 15$ & $144 \cdot 15$ & $144 \cdot 15$ & $144 \cdot 15$ \\
\hline Sucrose & 93 & 93 & 93 & 93 \\
\hline Microcrystalline cellulose & $46 \cdot 5$ & $46 \cdot 5$ & $46 \cdot 5$ & $46 \cdot 5$ \\
\hline Salt mix \#210050† & 32.55 & $32 \cdot 55$ & 32.55 & $32 \cdot 55$ \\
\hline Vitamin mix \#310025 & $9 \cdot 3$ & $9 \cdot 3$ & $9 \cdot 3$ & $9 \cdot 3$ \\
\hline L-Cystine & 1.674 & 1.674 & 1.674 & 1.674 \\
\hline Choline bitartrate & $2 \cdot 325$ & 2.325 & $2 \cdot 325$ & $2 \cdot 325$ \\
\hline$t$-Butylhydroquinone & 0.007 & 0.007 & 0.007 & 0.007 \\
\hline Soyabean oil & $37 \cdot 2$ & $37 \cdot 2$ & $37 \cdot 2$ & $37 \cdot 2$ \\
\hline Cellulose/maize starch (35:65) & 70 & - & 70 & - \\
\hline Nori or Konbu (freeze-dried) & - & 70 & - & 70 \\
\hline Cholesterol & - & - & $18 \cdot 6$ & $18 \cdot 6$ \\
\hline Cholic acid $\mathrm{Na}$ salt & - & - & 3.72 & 3.72 \\
\hline
\end{tabular}

* Dyetrose (carbohydrate composition) (\% by weight): monosaccharides 1 ; disaccharides 4; trisaccharides 5; tetrasaccharides and higher 90 .

† Mineral mix contained AIN-93M Mineral Mix (g/kg): calcium carbonate 357.00; potassium phosphate monobasic 250.00; potassium citrate $\mathrm{H}_{2} \mathrm{O} 28.00$; sodium chloride 74.00; potassium sulphate 46.60; magnesium oxide 24.00; ferric citrate U.S.P. 6.06; zinc carbonate 1.65; manganous carbonate 0.63 ; cupric carbonate 0.30 ; potassium iodate 0.01 ; sodium selenate 0.01 025; ammonium paramolybdate $4 \mathrm{H}_{2} \mathrm{O} 0.00795$; sodium metasilicate $9 \mathrm{H}_{2} \mathrm{O}$ 1.45; chromium potassium sulphate $12 \mathrm{H}_{2} \mathrm{O} 0.275$; lithium chloride 0.0174 ; boric acid 0.0815 ; sodium fluoride 0.0635 ; nickel carbonate 0.0318 ; ammonium vanadate 0.0066 ; sucrose finely powdered $209 \cdot 806$.

$\ddagger$ AIN-93VX Vitamin Mixture $(\mathrm{g} / \mathrm{kg})$ : niacin 3.00 , calcium pantothenate 1.60 , pyridoxine $\mathrm{HCl} 0.70$, thiamine $\mathrm{HCl} 0.60$, riboflavin 0.60 , folic acid 0.20 , biotin 0.02 , vitamin $E$ acetate $(335.57 \mathrm{mg} / \mathrm{g}) 15.00$, vitamin $B_{12}(0.1 \%) 2.50$, vitamin A palmitate $(150000 \mu \mathrm{g}$ retinol $/ \mathrm{g}) 0.80$, vitamin $D_{3}(10000 \mu \mathrm{g} / \mathrm{g}) 0.25$, vitamin $K_{1} /$ dextrose $\mathrm{mix}(10 \mathrm{mg} / \mathrm{g}) 7 \cdot 50$, sucrose $967 \cdot 23$. 


\section{Animals and maintenance}

Sixty growing male Wistar rats with a body weight of approximately $127 \mathrm{~g}$ at the outset were randomly divided into six groups of ten animals each, according to mean body weight. The rats were obtained from the breeding centre at the Facultad de Farmacia, Universidad Complutense de Madrid, Spain (Spanish Government Licence: ES 280790000085), and handled according to the 'Guide for the Care and Use of Laboratory Animals' published by the National Research Council $^{(26)}$. Animals were housed individually in metabolic cells in a temperature-controlled room $\left(22.3 \pm 1.8{ }^{\circ} \mathrm{C}\right)$ with a $12 \mathrm{~h} \mathrm{light/dark} \mathrm{cycle} \mathrm{and} \mathrm{fed} \mathrm{one} \mathrm{of} \mathrm{six} \mathrm{experimental} \mathrm{diets}$ for 3 weeks. The study was approved by the Spanish Science and Technology Advisory Committee and by an ethics committee of the Facultad de Farmacia of the Universidad Complutense de Madrid (Spain).

\section{Dietary treatments}

After weaning, rats were fed commercial rat pellets (Panlab, Barcelona, Spain) during a 1 -week period of adaptation to environmental conditions and then switched to the experimental diets. All diets contained approximately $13 \%$ protein, $4 \%$ fat and $7 \%$ total dietary fibre (Table 1 ). Water and food were provided ad libitum over the 3-week-long experiment that was considered adequate to observe significant results on lipoproteinaemia ${ }^{(27)}$. Food intake was checked daily and body weight variations were measured on alternate days. The dietary efficiency ratio was used to determine the relationship between body weight gain $(\mathrm{g})$ and food intake $(\mathrm{g})$, while apparent diet digestibility, i.e. the percentage of food digested and absorbed, was calculated using the formula $(100 \times($ Food intake - faecal weight/food intake)). Both parameters are frequently employed in animal nutrition studies to evaluate food digestibility and utilisation.

To have an adequate postprandial lipaemia or lipoproteinaemia curve, a minimum of six points are needed. As lipoprotein determination requires a relatively large amount $(1-2 \mathrm{ml})$ of serum or plasma ${ }^{(28)}$, we were unable to obtain the area under the curve for rat postprandial lipoproteinaemia. Thus, the $3 \mathrm{~h}$ time point, frequently used to determine postprandial lipaemia, was chosen for the present study, as this is the point at which lipaemia values are usually the highest ${ }^{(11,29)}$.

At the end of the trial, rats had free access to food until between 05.00 hours and 06:30 hours and were euthanatised, after a $3 \mathrm{~h}$ diet withdrawal, between 08.00 hours and 09.30 hours. One animal at a time was taken at random from each of the six groups, anesthetised with an intraperitoneal injection of sodium pentobarbital $(45 \mathrm{mg} / \mathrm{kg}$ body weight) and euthanatised by extracting blood from the descending aorta with a syringe.

\section{Lipoprotein isolation}

Blood from the descending aorta was collected into heparinised tubes. Plasma was separated from whole blood within $30 \mathrm{~min}$ of collection by centrifugation at $2500 \mathrm{rpm}(1500 \mathrm{~g})$ for $20 \mathrm{~min}$ and kept at $4^{\circ} \mathrm{C}$ until lipoprotein isolation.

Lipoproteins (chylomicrons, VLDL, LDL and HDL fractions) were isolated from plasma by density gradient ultracentrifugation. Chylomicrons were obtained by aspiration after $27 \mathrm{~min}$ at $30000 \mathrm{rpm}(153000 \mathrm{~g})$ and $4^{\circ} \mathrm{C}$ ultracentrifugation in a Beckman L8-70M ultracentrifuge, SW-40.1 rotor (Palo Alto, CA, USA), following a slight modification of the Terpstra method ${ }^{(30)}$ by using quick acceleration and deceleration rates. After chylomicrons were isolated, tubes were filled with distilled water and ultracentrifuged for $21 \mathrm{~h} 40 \mathrm{~min}$ at $40000 \mathrm{rpm}(272000 \mathrm{~g})$ and $4^{\circ} \mathrm{C}$ in a Beckman L8-70M ultracentrifuge, SW-40.1 rotor, following a slight modification of the method of Terpstra et al. ${ }^{(28)}$, without staining lipoproteins. Tubes were volume calibrated ${ }^{(28,30)}$ and lipoproteins were separated by tube slicing at the density range of VLDL $\left(\rho_{20}<1.0063 \mathrm{~g} / \mathrm{ml}\right)$, LDL $\left(1.0063<\rho_{20}<1.057 \mathrm{~g} / \mathrm{ml}\right)$ and HDL $\left(1.057<\rho_{20}<1.21 \mathrm{~g} / \mathrm{ml}\right)$.

\section{Plasma lipid and lipoprotein lipid analyses}

Total cholesterol, TAG and phospholipid contents were determined in plasma, chylomicrons and VLDL, LDL and HDL fractions by standard enzymatic analysis (Boehringer, Manheim, Germany). All intra-assay and inter-assay coefficients of variation were $<5.5 \%$. Protein content in the isolated lipoproteins was determined by the Lowry et al. ${ }^{(31)}$ method. Total lipids were calculated as the sum of cholesterol, TAG and phospholipids. A given lipoprotein mass was calculated as the sum of lipids and proteins (both in $\mathrm{mg} / \mathrm{l}$ ) in this lipoprotein.

\section{Arylesterase activity measurement}

Rat plasma AE activity was measured following the Nus et al. ${ }^{(15,32)}$ method. Reaction rates were monitored at $270 \mathrm{~nm}$ in thermostated quartz cuvettes with a $10 \mathrm{~mm}$ light path using a Shimadzu UV-2401 PC (Tokyo, Japan) spectrophotometer. Blanks without plasma samples were used to correct for the spontaneous hydrolysis of phenylacetate in the buffer. Each measurement was performed in duplicate.

\section{Statistical analyses}

Statistical analyses were performed using SPSS version 15.0 statistical analysis packages (SPSS Inc., Chicago, IL, USA). Results were expressed as mean values and standard deviation. Two-way ANOVA (type of diet, control, Nori and Konbu; and cholesterol-enriched or non-cholesterol-enriched diet) was used to compare responses to diet in the six groups. Pairwise comparisons of diet responses between groups were made employing the Bonferroni test. The effect of cholesterol consumption was evaluated using an unpaired Student's $t$ test. Differences were accepted as significant when $P<0 \cdot 05$.

\section{Results}

\section{Total food intake}

In the present study, rats in the six experimental groups consumed similar amounts of food. Thus, total food intake was not significantly affected by dietary cholesterol or alga content (Table 2). 
Body weight gain, dietary efficiency ratio, faecal weight and apparent diet digestibility

Body weight gain ranged between 125.2 and $158.0 \mathrm{~g}$. Weight gain was affected by the cholesterol supplement $(P<0 \cdot 05)$, but not by the diet type $(P<0 \cdot 1)$. The lowest weight gain was displayed by the Chol-C group, followed by the Chol-K group (Table 2).

Dietary efficiency ratio, faecal weight and apparent diet digestibility were significantly affected $(P<0 \cdot 01, P<0.01$ and $P<0.05$, respectively) by the cholesterol diet-type interaction (Table 2). Dietary efficiency ratio was significantly decreased $(P<0.001)$ by cholesterol consumption. However, this effect was not observed in NCholK $v$. Chol-K animals. Inclusion of seaweeds in both the NChol and Chol diets significantly increased $(P<0 \cdot 001)$ faecal weights. The highest faecal weight values among NChol animals were seen in the NChol-K group, while the highest values among Chol rats were those of the Chol-N group. NChol-N and NChol-K rats displayed lower apparent diet digestibility values than animals fed the NChol-C diet. Dietary cholesterol supplementation decreased (at least $P<0.05$ ) apparent diet digestibility in all groups (Table 2).

\section{Lipaemia}

Data of postprandial plasma lipids for the different groups are shown in Table 3. TAG levels were significantly affected $(P<0.05)$ by the cholesterol diet-type interaction. Supplementary cholesterol $(P<0.001)$ and diet type (at least $P<0.05)$ significantly modified plasma cholesterol and total lipid values, while diet type $(P<0 \cdot 01)$ significantly influenced phospholipid concentrations. The cholesterol/phospholipid ratio was significantly affected by dietary cholesterol $(P<0 \cdot 001)$. NChol-K rats presented significantly higher (at least $P<0.05)$ plasma cholesterol, TAG, phospholipid and total lipid values than NChol-C animals, while concentrations of these parameters of Chol-N and Chol- $\mathrm{K}$ rats were not significantly different than those of Chol-C animals. The postprandial triacylglycerolaemia was significantly decreased $(P<0.001)$ by supplementary cholesterol in Chol-K and Chol-N groups. Chol-N rats presented significantly lower $(P<0.05)$ plasma cholesterol levels than Chol-K animals.

\section{Lipoproteinaemia}

Table 4 shows the lipid and protein contents of the different lipoprotein fractions. A significant cholesterol diet-type interaction was observed for cholesterol of chylomicrons $(P<0.05)$; TAG of chylomicrons $(P<0.001)$, VLDL $(P<0.01)$ and LDL $(P<0.001)$; phospholipids of chylomicrons $(P<0.05)$, VLDL $(P<0.01)$, LDL $(P<0.001)$ and HDL $(P<0.05)$; total lipids of chylomicrons $(P<0.001)$, LDL $(P<0.001)$ and HDL $(P<0.05)$; proteins of chylomicrons $(P<0.001)$ and HDL $(P<0.001)$; and total mass of chylomicrons $(P<0.001)$, LDL $(P<0.001)$ and HDL $(P<0.01)$.

When dietary effect was separately studied in NChol and Chol animals, levels of VLDL cholesterol and LDL cholesterol; TAG of chylomicrons and LDL; phospholipids of chylomicrons; total lipids of chylomicrons and LDL; protein of chylomicrons, VLDL and HDL; and total lipoprotein 
mass of chylomicrons, VLDL, LDL and HDL were observed to be significantly higher (at least $P<0.05$ ) in NChol-K rats than in NChol-C ones. Very few significant changes were induced by the NChol-N diet. Due to the type of diet, levels of cholesterol in chylomicrons; TAG in VLDL and LDL; phospholipids in VLDL and LDL; total lipids in LDL and HDL; proteins in chylomicrons and LDL; and lipoprotein mass in LDL differed significantly between Chol-N and Chol-C animals. Phospholipids of chylomicrons and proteins of LDL were significantly higher (at least $P<0.05$ ) in Chol-K than in Chol-C rats.

The addition of cholesterol to the diet significantly affected $(P<0.001)$ the concentrations of lipids (except phospholipids, total lipids and lipoprotein mass in the chylomicrons) and proteins in the various lipoprotein fractions. The amount of cholesterol in the VLDL and chylomicron fractions increased severalfold with the cholesterol-enriched diets (Table 4).

Because the principal objective of the present study was to determine the effect of algae on postprandial lipoproteinaemia, which is mainly affected by chylomicrons and VLDL, only the composition of chylomicrons and VLDL (given as percentage contribution of the different lipids and proteins) is presented in Table 5. The percentage contributions of all components of chylomicrons and those of TAG and proteins of VLDL were significantly affected by the cholesterol diet-type interaction. When NChol and Chol rats were separately studied, chylomicrons of NChol-K rats presented lower cholesterol but higher protein percentages than chylomicrons of NChol-C animals, while VLDL of NChol-K rats had lower phospholipid and higher protein percentages than VLDL of NChol-C animals. Chylomicrons of NChol-N rats had higher TAG and lower protein percentages than chylomicrons of NChol-C, while chylomicrons of NChol-N had lower protein percentages than chylomicrons of NChol-K; VLDL of NChol-N had lower phospholipid and higher protein percentages than VLDL of NChol-C. With regard to the Chol animals, chylomicrons of Chol-N rats had lower TAG levels but higher cholesterol and protein percentages than those of Chol-C rats, while VLDL of Chol-N animals had percentually more proteins than VLDL of Chol-C rats. Chylomicrons of Chol-K rats had lower TAG but higher phospholipid percentages (both $P<0.05$ ) than those of their Chol-C counterparts, while VLDL of Chol-K animals had higher protein percentages $(P<0.05)$ than VLDL of Chol-C rats. Cholesterol and TAG protein percentage contributions to chylomicrons and VLDL were significantly affected by cholesterol supplementation (at least $P<0.01$ ) in all groups (Table 5).

A comparison of cholesterol and TAG transport by the different lipoproteins is presented in Figs 1 and 2, respectively. In general terms, transport of cholesterol and TAG was significantly affected (at least $P<0.05$ ) by the dietary cholesterol supplement and the type of diet. While HDL was the main cholesterol carrier in NChol rats, VLDL was the major cholesterol carrier in Chol rats.

\section{Arylesterase activity}

A significant cholesterol diet-type interaction (at least $P<0.05)$ was found when $\mathrm{AE}$ activity was normalised adjusted for HDL cholesterol, HDL lipids, HDL phospholipids and HDL mass. NChol-N and NChol-K rats 
Table 4. Postprandial lipoprotein lipid concentrations in rats fed the control, Nori and Konbu experimental diets with and without a cholesterol supplement (Mean values and standard deviations of ten animals)

\begin{tabular}{|c|c|c|c|c|c|c|c|c|c|c|}
\hline & \multirow[b]{2}{*}{ Supplementary cholesterol } & \multicolumn{2}{|c|}{ Control } & \multicolumn{2}{|c|}{ Nori } & \multicolumn{2}{|c|}{ Konbu } & \multicolumn{3}{|c|}{ ANOVA } \\
\hline & & Mean & SD & Mean & SD & Mean & SD & Cholesterol effect & Diet effect & Interaction \\
\hline \multicolumn{11}{|c|}{ Cholesterol (mg/l) } \\
\hline \multirow[t]{2}{*}{ QM } & No & $8 \cdot 30$ & 3.80 & $10 \cdot 90$ & $7 \cdot 00$ & $9 \cdot 10$ & $2 \cdot 70$ & $<0.001$ & $<0.01$ & $<0.05$ \\
\hline & Yes & $74 \cdot 40^{a \star \star \star}$ & 41.50 & $122 \cdot 7^{b \star \star \star}$ & 33.60 & $99.00^{\mathrm{ab} * \star *}$ & $23 \cdot 70$ & & & \\
\hline \multirow{2}{*}{ VLDL } & No & $56 \cdot 40^{\mathrm{a}}$ & $23 \cdot 10$ & $78 \cdot 80^{\mathrm{ab}}$ & $30 \cdot 00$ & $91.60^{b}$ & $26 \cdot 90$ & $<0.001$ & NS & NS \\
\hline & Yes & $1380 \cdot 0^{\star \star \star}$ & 663.0 & $1095 \cdot 0^{* \star \star}$ & 251.5 & $1637 \cdot 0^{\star \star \star}$ & 514.0 & & & \\
\hline \multirow[t]{2}{*}{ LDL } & No & $74.40^{\mathrm{a}}$ & 11.00 & $77 \cdot 60^{\mathrm{a}}$ & $18 \cdot 30$ & $100 \cdot 5^{\mathrm{b}}$ & $16 \cdot 40$ & $<0.001$ & $<0.05$ & NS \\
\hline & Yes & $149 \cdot 8^{* *}$ & 78.90 & $125 \cdot 0^{\star \star \star}$ & $30 \cdot 20$ & $177 \cdot 1^{\star *}$ & $59 \cdot 40$ & & & \\
\hline \multirow[t]{2}{*}{$\mathrm{HDL}$} & No & $496 \cdot 5$ & 128.0 & 487.5 & 83.50 & $532 \cdot 7$ & 69.00 & $<0.001$ & NS & NS \\
\hline & Yes & $278 \cdot 1^{\star \star \star}$ & $66 \cdot 80$ & $322 \cdot 5^{\star \star *}$ & $102 \cdot 1$ & $268 \cdot 6^{\star \star *}$ & $64 \cdot 10$ & & & \\
\hline \multicolumn{11}{|c|}{ TAG $(\mathrm{mg} / \mathrm{l})$} \\
\hline \multirow[t]{2}{*}{ QM } & No & $175 \cdot 9^{a}$ & 63.40 & $342 \cdot 4^{\mathrm{b}}$ & $107 \cdot 5$ & $449 \cdot 5^{\mathrm{b}}$ & $127 \cdot 5$ & $<0.001$ & $<0.001$ & $<0.001$ \\
\hline & Yes & $265 \cdot 7^{\star \star}$ & $43 \cdot 30$ & $201 \cdot 8^{\star \star \star}$ & 20.60 & $248 \cdot 3^{\star \star \star}$ & 84.60 & & & \\
\hline \multirow[t]{2}{*}{ VLDL } & No & 671.8 & 46.90 & $732 \cdot 1$ & 87.90 & 726.7 & $61 \cdot 80$ & $<0.001$ & $<0.001$ & $<0.01$ \\
\hline & Yes & $386 \cdot 1^{a * \star *}$ & $72 \cdot 40$ & $483 \cdot 1^{\mathrm{b} * \star *}$ & $46 \cdot 80$ & $342 \cdot 8^{a \star \star \star}$ & $45 \cdot 80$ & & & \\
\hline \multirow[t]{2}{*}{ LDL } & No & $43.00^{\mathrm{a}}$ & $14 \cdot 10$ & $54 \cdot 00^{\mathrm{ab}}$ & $20 \cdot 10$ & $74.00^{\mathrm{b}}$ & $27 \cdot 10$ & $<0.01$ & $<0.01$ & $<0.001$ \\
\hline & Yes & $160 \cdot 0^{a \star \star \star}$ & $82 \cdot 30$ & $55.00^{\mathrm{b}}$ & $40 \cdot 80$ & $47.00^{\mathrm{b}}$ & 33.60 & & & \\
\hline \multirow{2}{*}{$\mathrm{HDL}$} & No & $226 \cdot 0$ & $124 \cdot 5$ & $207 \cdot 0$ & $56 \cdot 10$ & $242 \cdot 0$ & $84 \cdot 30$ & $<0.001$ & NS & NS \\
\hline & Yes & $103 \cdot 0^{*}$ & $72 \cdot 50$ & $116 \cdot 0^{\star *}$ & $72 \cdot 40$ & $121 \cdot 0^{\star \star}$ & 65.90 & & & \\
\hline \multicolumn{11}{|c|}{ Phospholipids (mg/l) } \\
\hline \multirow[t]{2}{*}{ QM } & No & $17 \cdot 90^{\mathrm{a}}$ & 5.20 & $22 \cdot 50^{\mathrm{a}}$ & 11.80 & $39.60^{b}$ & $8 \cdot 30$ & $<0.001$ & $<0.001$ & $<0.05$ \\
\hline & Yes & $28 \cdot 00^{a *}$ & 12.00 & $30 \cdot 00^{\mathrm{a}}$ & 9.40 & $69 \cdot 00^{\mathrm{b} * *}$ & $22 \cdot 30$ & & & \\
\hline \multirow[t]{2}{*}{ VLDL } & No & $156 \cdot 0$ & $29 \cdot 10$ & $142 \cdot 0$ & $18 \cdot 10$ & $146 \cdot 0$ & $23 \cdot 10$ & $<0.001$ & $<0.001$ & $<0.01$ \\
\hline & Yes & $443 \cdot 0^{a * \star *}$ & $78 \cdot 70$ & $336 \cdot 0^{\mathrm{b} * \star *}$ & 41.90 & $456 \cdot 0^{a \star \star \star}$ & $80 \cdot 70$ & & & \\
\hline \multirow[t]{2}{*}{ LDL } & No & 44.00 & 8.40 & 51.00 & 9.90 & 49.00 & 11.90 & $<0.001$ & $<0.001$ & $<0.001$ \\
\hline & Yes & $224 \cdot 0^{a \star \star *}$ & 52.90 & $109 \cdot 0^{\mathrm{b} * \star *}$ & 28.40 & $267 \cdot 2^{a \star \star \star}$ & 93.20 & & & \\
\hline \multirow[t]{2}{*}{$\mathrm{HDL}$} & No & $1016 \cdot 0$ & 203.6 & $1091 \cdot 0$ & 174.4 & $1189 \cdot 0$ & 183.6 & $<0.001$ & $<0.05$ & $<0.05$ \\
\hline & Yes & $503 \cdot 4^{a \star \star \star}$ & 158.4 & $729 \cdot 2^{\mathrm{b} * \star \star}$ & 148.4 & $515 \cdot 1^{a \star \star \star}$ & 162.5 & & & \\
\hline Total lipi & $\mathrm{ng} / \mathrm{l}) \dagger$ & & & & & & & & & \\
\hline QM & No & $202 \cdot 1^{a}$ & 60.40 & $375 \cdot 8^{b}$ & $112 \cdot 1$ & $498.2^{c}$ & $127 \cdot 3$ & NS & $<0.001$ & $<0.001$ \\
\hline & Yes & $368 \cdot 1$ & 57.40 & 354.5 & 53.20 & $416 \cdot 3$ & $81 \cdot 20$ & & & \\
\hline VLDL & No & 884.2 & $64 \cdot 10$ & 952.9 & $96 \cdot 30$ & 964.3 & 87.90 & $<0.001$ & NS & NS \\
\hline & Yes & $2209 \cdot 0^{\star * *}$ & 671.0 & $1914 \cdot 0^{\star \star \star}$ & 292.2 & $2436 \cdot 0^{\star \star \star}$ & $547 \cdot 1$ & & & \\
\hline LDL & No & $161.4^{\mathrm{a}}$ & $22 \cdot 80$ & $182 \cdot 6^{\mathrm{a}}$ & $22 \cdot 50$ & $223.5^{\mathrm{b}}$ & $30 \cdot 30$ & $<0.001$ & $<0.001$ & $<0.001$ \\
\hline & Yes & $533 \cdot 8^{a \star \star \star}$ & $104 \cdot 1$ & $289 \cdot 0^{\mathrm{b} * \star *}$ & $67 \cdot 20$ & $491 \cdot 3^{a \star \star \star}$ & 79.60 & & & \\
\hline $\mathrm{HDL}$ & No & 1739.0 & $281 \cdot 0$ & $1785 \cdot 0$ & $232 \cdot 2$ & 1964.0 & 291.5 & $<0.001$ & NS & $<0.05$ \\
\hline & Yes & $884 \cdot 5^{\mathrm{a} * \star *}$ & $245 \cdot 3$ & $1168 \cdot 0^{\mathrm{b} * \star \star}$ & 263.3 & $904 \cdot 7^{\mathrm{ab} * \star \star}$ & 174.1 & & & \\
\hline Protein ( & & & & & & & & & & \\
\hline QM & No & $9 \cdot 10^{\mathrm{a}}$ & 1.10 & $6 \cdot 50^{\mathrm{a}}$ & 2.90 & $12 \cdot 50^{\mathrm{b}}$ & 3.80 & $<0.001$ & $<0.01$ & $<0.001$ \\
\hline & Yes & $15 \cdot 00^{a \star \star \star}$ & 3.10 & $21 \cdot 50^{b \star \star \star}$ & 3.00 & $17 \cdot 60^{\mathrm{a} \star \star}$ & 3.00 & & & \\
\hline VLDL & No & $89.00^{\mathrm{a}}$ & $19 \cdot 10$ & $123 \cdot 5^{\mathrm{b}}$ & $19 \cdot 10$ & $146 \cdot 6^{\mathrm{b}}$ & 44.40 & $<0.001$ & $<0.001$ & NS \\
\hline & Yes & $326 \cdot 0^{a \star \star \star}$ & 98.50 & $405 \cdot 0^{\mathrm{ab} * \star *}$ & 97.60 & $453 \cdot 0^{\mathrm{b} \star \star \star}$ & $76 \cdot 30$ & & & \\
\hline LDL & No & $185 \cdot 0^{\mathrm{a}}$ & 33.00 & $123 \cdot 5^{\mathrm{b}}$ & 24.50 & $170 \cdot 0^{\mathrm{a}}$ & 32.90 & $<0.001$ & $<0.001$ & NS \\
\hline & Yes & $245 \cdot 0^{a \star \star}$ & 51.60 & $163 \cdot 0^{\mathrm{b} *}$ & 35.90 & $242 \cdot 0^{a \star \star \star}$ & 37.00 & & & \\
\hline $\mathrm{HDL}$ & No & $851 \cdot 0^{\mathrm{a}}$ & 73.00 & $903 \cdot 0^{\mathrm{a}}$ & $118 \cdot 1$ & $1202 \cdot 0^{\mathrm{b}}$ & $255 \cdot 2$ & $<0.001$ & $<0.001$ & $<0.001$ \\
\hline & Yes & $282 \cdot 0^{\star \star \star}$ & $65 \cdot 70$ & $253 \cdot 0^{\star \star \star}$ & 39.10 & $255 \cdot 0^{\star \star \star}$ & $66 \cdot 20$ & & & \\
\hline
\end{tabular}


presented significantly higher $\mathrm{AE}$ activity levels $(P<0.05)$ than NChol-C animals. AE activity decreased significantly (at least $P<0.05$ ) in all groups receiving supplementary cholesterol. Similar effects were observed when data were adjusted for cholesterol and VLDL mass contents (Table 6).

\section{Discussion}

Food consumption and body weight changes

Diets containing Konbu and Nori were well accepted, and consumed at a rate similar to that of control diets ${ }^{(3)}$. Results on body weight changes in the present study are comparable with those reported by Wong et al. ${ }^{(33)}$ and Sánchez-Muniz et al. ${ }^{(27)}$ in rats.

\section{Lipidemia and lipoproteinaemia}

Postprandial lipaemia and triacylglycerolaemia values of NChol-C rats were similar to those found in other studies $^{(11,34)}$, but elevated with respect to others performed in comparison with those observed in fasted rats ${ }^{(27,34)}$. Nonetheless, cholesterolaemia and phospholipaemia values in the normocholesterolaemic NChol-C rats of the present study were similar to those reported in fasted animals ${ }^{(27)}$ with all NChol-C rats being normocholesterolaemics ${ }^{(35)}$. Thus, the non-fasting condition mainly affects TAG-rich lipoproteins. The absolute content and composition of LDL and HDL in the NChol-C group were comparable with those reported in other studies ${ }^{(36)}$. HDL cholesterol and HDL lipids account for $70 \%$ or more of total cholesterol and lipaemia. Cholesterol ester transfer protein activity is very low in rats ${ }^{(37)}$, explaining, at least in part, the present results. Rats, moreover, display a very effective uptake of VLDL and a low transference of apo B from VLDL to $\mathrm{LDL}^{(38)}$, which explains the low levels of LDL found in the present study and in previous ones ${ }^{(27,33,35,36)}$.

Consumption of the NChol-K diet increased all lipoprotein masses, suggesting increased production of all rat lipoproteins, while that of the NChol-N diet increased only chylomicron mass, suggesting that those chylomicrons metabolism were slowed down. Differences in lipid and lipoprotein levels between NChol groups must first be attributed to the different fibre composition of the diets and secondly to other compounds, such as minerals, that may also affect postprandial lipaemia ${ }^{(5,39)}$. A previous publication involving the rats of the present study ${ }^{(40)}$ reported that alga remains were found in the cecum of NChol-K rats, but not in NChol-N animals, suggesting clear differences in gastric emptying time and digestion speed between both alga diets. Nori contains more viscous-soluble fibre than Konbu, partially explaining why the $3 \mathrm{~h}$ postprandial lipaemia values of NChol-K rats were higher than those of their NChol-N counterparts. However, the cellulose consumed by the NChol-C rats, in contrast to the algal fibre consumed by the NChol-N and NChol-K animals, accelerates the digestion process and the chylomicrons metabolisation. NChol-N chylomicrons presented higher TAG and lower protein levels than NChol-K and NChol-C chylomicrons, suggesting a lower degree of metabolisation due to their more recent presence in plasma. Olson \& Schneeman ${ }^{(11)}$ reported that after a $4 \cdot 5$-h period of food 
Table 5. Percentage contribution of the different lipids and proteins to the total mass of the different lipoproteins in rats fed the control, Nori and Konbu experimental diets with and without supplementary cholesterol

(Mean values and standard deviations for ten animals)

\begin{tabular}{|c|c|c|c|c|c|c|c|c|c|c|}
\hline & \multirow[b]{2}{*}{ Supplementary cholesterol } & \multicolumn{2}{|c|}{ Control } & \multicolumn{2}{|c|}{ Nori } & \multicolumn{2}{|c|}{ Konbu } & \multicolumn{3}{|c|}{ ANOVA } \\
\hline & & Mean & SD & Mean & SD & Mean & SD & Cholesterol effect & Diet effect & Interaction \\
\hline \multicolumn{11}{|l|}{ Chylomicrons } \\
\hline \multirow[t]{2}{*}{ TAG } & No & $81.54^{\mathrm{a}}$ & 7.41 & $89.45^{b}$ & 3.86 & $87.39^{\mathrm{ab}}$ & $3 \cdot 21$ & $<0.001$ & NS & $<0.001$ \\
\hline & Yes & $69 \cdot 80^{a * \star}$ & $8 \cdot 11$ & $54 \cdot 16^{\mathrm{b} * * *}$ & $5 \cdot 02$ & $56 \cdot 14^{\mathrm{b} * \star \star}$ & 8.73 & & & \\
\hline \multirow[t]{2}{*}{ Cholesterol } & No & $4 \cdot 39^{\mathrm{a}}$ & $2 \cdot 29$ & $3.09^{\mathrm{ab}}$ & 1.98 & $1.91^{\mathrm{b}}$ & 0.90 & $<0.001$ & $<0.001$ & $<0.001$ \\
\hline & Yes & $18 \cdot 87^{a \star \star \star}$ & 9.02 & $32 \cdot 15^{\mathrm{b} \star \star \star}$ & 4.91 & $23.42^{\mathrm{a} \star \star \star}$ & $6 \cdot 68$ & & & \\
\hline \multirow[t]{2}{*}{ Phospholipids } & No & 9.50 & 4.52 & $5 \cdot 83$ & 2.59 & 8.26 & $2 \cdot 77$ & $<0.01$ & $<0.001$ & $<0.001$ \\
\hline & Yes & $7.43^{\mathrm{a}}$ & 3.38 & $7.96^{a *}$ & 1.96 & $16 \cdot 38^{b * \star \star}$ & 6.01 & & & \\
\hline \multirow[t]{2}{*}{ Proteins } & No & $4.57^{\mathrm{a}}$ & 1.09 & $1.64^{\mathrm{b}}$ & 0.33 & $2.43^{\mathrm{c}}$ & 0.31 & $<0.001$ & $<0.001$ & $<0.001$ \\
\hline & Yes & $3.89^{\mathrm{a}}$ & 0.28 & $5 \cdot 73^{\mathrm{b} * \star *}$ & 0.32 & $4 \cdot 07^{a * \star *}$ & 0.29 & & & \\
\hline \multicolumn{11}{|l|}{ VLDL } \\
\hline \multirow{2}{*}{ TAG } & No & 69.14 & $2 \cdot 37$ & 67.96 & 4.25 & 65.66 & 3.57 & $<0.001$ & $<0.001$ & $<0.05$ \\
\hline & Yes & $16 \cdot 69^{\mathrm{ab} * \star \star}$ & 5.96 & $21 \cdot 29^{a \star \star \star}$ & 3.81 & $12 \cdot 51^{\mathrm{b} * \star *}$ & $3 \cdot 70$ & & & \\
\hline \multirow[t]{2}{*}{ Cholesterol } & No & $5 \cdot 77$ & 2.38 & $7 \cdot 26$ & 2.37 & $8 \cdot 19$ & 1.95 & $<0.001$ & $<0.05$ & NS \\
\hline & Yes & $51 \cdot 60^{\star \star \star}$ & 11.73 & $46 \cdot 78^{\star \star \star}$ & 3.59 & $55 \cdot 54^{\star \star \star}$ & $6 \cdot 24$ & & & \\
\hline \multirow[t]{2}{*}{ Phospholipids } & No & $16 \cdot 03^{\mathrm{a}}$ & 2.75 & $13 \cdot 33^{b}$ & $2 \cdot 32$ & $13 \cdot 16^{b}$ & 1.67 & $<0.01$ & $<0.01$ & NS \\
\hline & Yes & $18 \cdot 76$ & $6 \cdot 22$ & 14.64 & 1.47 & $16 \cdot 09^{\star \star}$ & 2.59 & & & \\
\hline \multirow{2}{*}{ Proteins } & No & $9 \cdot 07^{\mathrm{a}}$ & 1.21 & $11.45^{\mathrm{b}}$ & 1.05 & $12.99^{b}$ & $2 \cdot 84$ & $<0.001$ & $<0.001$ & $<0.05$ \\
\hline & Yes & $12 \cdot 94^{\mathrm{a} \star \star \star}$ & 0.89 & $17 \cdot 29^{b * \star \star}$ & 1.97 & $15 \cdot 86^{\mathrm{b} * *}$ & 1.09 & & & \\
\hline
\end{tabular}

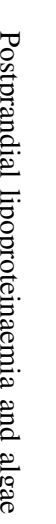

a,b,c Mean values within a row with unlike superscript letters were significantly different $(P<0.05$, Bonferroni test)

Mean values were significantly different from those of the no supplementary cholesterol counterparts: ${ }^{*} P<0.05,{ }^{* \star} P<0.01,{ }^{\star \star *} P<0.001$ 




Fig. 1. Relative cholesterol transport by different lipoproteins in rats consuming control, Nori and Konbu diets with and without supplementary cholesterol. NChol-C, rats fed the control diet without supplementary cholesterol; NChol-N, rats fed the Nori diet without supplementary cholesterol; $\mathrm{NChol-K}$, rats fed the Konbu diet without supplementary cholesterol; Chol-C, rats fed the control diet with supplementary cholesterol; Chol-N, rats fed the Nori diet with supplementary cholesterol; Chol-K, rats fed the Konbu diet with supplementary cholesterol. $\mathbb{1}$, chylomicrons, $\square$, VLDL; LDL; $\boxminus, \mathrm{HDL}$ ${ }^{\star \star \star} P<0.001$, supplementary cholesterol $v$. no supplementary cholesterol. Values for the same lipoprotein within the groups fed the supplementary cholesterol diets bearing a different letter were significantly different $(P<0.05)$.

deprivation, rats fed oat bran displayed higher plasma TAG levels (in the form of TAG-rich lipoproteins) than rats given cellulose, but the fibre type did not affect postprandial plasma and lipoprotein cholesterol levels. Plasma TAG levels were lower after meals including fibre in the form of guar gum ${ }^{(41)}$, oat bran, wheat fibre or wheat germ $^{(42)}$ than after meals without fibre. Other investigators have reported that certain dietary fibres enhanced postprandial lipaemia ${ }^{(43)}$. The accumulation of TAG-rich lipoproteins after a meal is most likely due to delayed clearance ${ }^{(11,44)}$. The NChol-K diet contained higher amounts of arsenic and a higher $\mathrm{Zn} / \mathrm{Cu}$

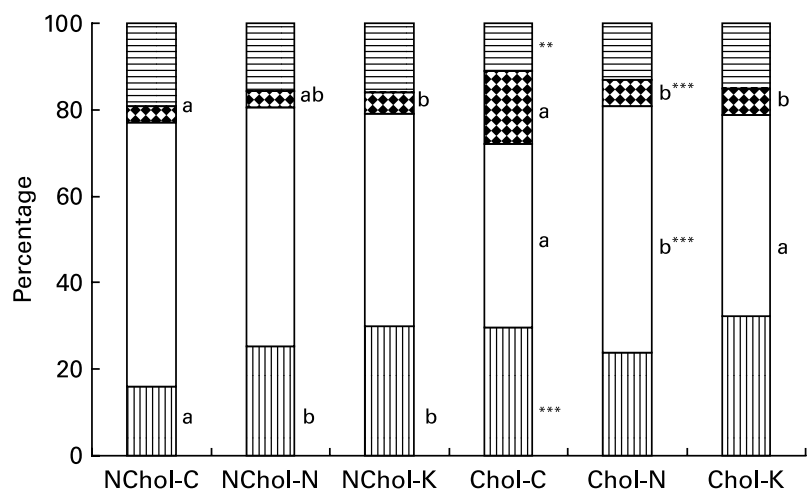

Fig. 2. Relative TAG transport by different lipoproteins in rats consuming control, Nori and Konbu diets with and without supplementary cholesterol. $\mathrm{NChol}-\mathrm{C}$, rats fed the control diet without supplementary cholesterol; NChol-N, rats fed the Nori diet without supplementary cholesterol; NChol-K, rats fed the Konbu diet without supplementary cholesterol; Chol-C, rats fed the control diet with supplementary cholesterol; Chol-N, rats fed the Nori diet with supplementary cholesterol; Chol-K, rats fed the Konbu diet with supplementary cholesterol. ${ }^{\star \star} P<0.01 ;{ }^{* \star *} P<0.001$, supplementary cholesterol $v$. no supplementary cholesterol. Values for the same lipoprotein within the groups fed the supplementary cholesterol diets or the groups fed the non-supplementary cholesterol diets bearing a different letter were

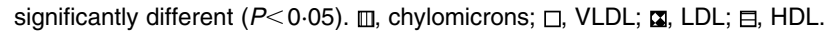

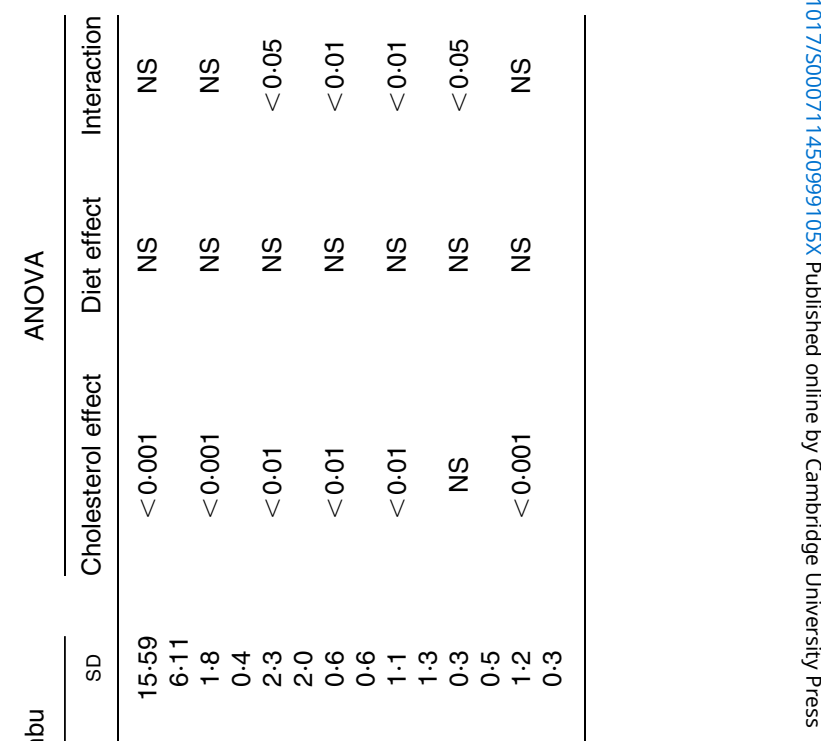

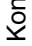



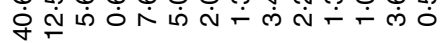

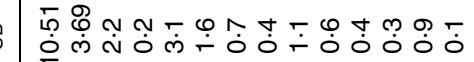

든

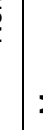

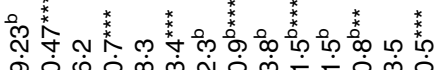

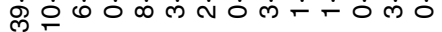

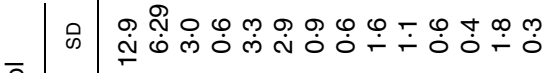

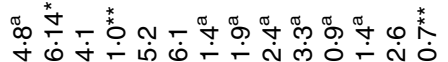
$\stackrel{\text { ஸे }}{\circ}$ 
ratio than the NChol-N or NChol-C diets. According to States et al. ${ }^{(45)}$, epidemiological studies have shown that chronic arsenic exposure is associated with increased CVD morbidity and mortality. Klevay ${ }^{(46)}$ found that the hypercholesterolaemic effect of diets is related to the $\mathrm{Zn} / \mathrm{Cu}$ dietary ratio.

Postprandial results in rats fed cholesterol-enriched diets suggest that supplementary dietary cholesterol modified the effect of fibre on gastric emptying time. The inclusion of the hypercholesterolaemic agent together with Nori or Konbu partially but significantly blocked the postprandial hypertriglyceridaemic effects induced by these algae in the NChol animals. Moreover, chylomicrons of Chol-N animals contained more cholesterol and fewer TAG than chylomicrons of Chol-C rats. Phospholipid levels greatly increased in the chylomicron particles of Chol-K rats, suggesting the remodelling of these lipoproteins. Postprandial plasma cholesterol increased in Chol rats mainly as a result of the cholesterol enrichment of $\operatorname{VLDL}^{(27,47,48)}$. However, in comparison with the postprandial cholesterol and VLDL cholesterol levels of Chol-C rats, those of Chol-N animals were 25 and $21 \%$ lower, respectively, while those of Chol-K rats were 15 and $18.6 \%$ higher, respectively. Nori has more solubility than $\mathrm{Konbu}^{(3,5)}$, which would explain the differences found in plasma and lipoprotein cholesterol levels between these two dietary groups. Water-soluble fractions of seaweeds or isolated algal polysaccharides induce hypocholesterolaemic effects in experimental animals ${ }^{(5,6)}$. As previously commented, Konbu has a higher $\mathrm{Zn} / \mathrm{Cu}$ ratio ${ }^{(49)}$, and higher concentrations of arsenic than Nori, which may explain why the Chol-K diet is less hypocholesterolaemic than the Chol-N $\operatorname{diet}^{(49)}$.

Postprandial HDL cholesterol and HDL mass levels in the Chol-C group were lower than those of the NChol-C rats (Fig. 1). Lower HDL cholesterol levels have been previously described in rats given cholesterol supplements ${ }^{(27,50)}$. Little is known about the mechanisms responsible for those results, although the reduction may be due to increased uptake of HDL by SR-B1 receptors ${ }^{(51)}$. This lipoprotein cholesterol is used in the final step of the reverse cholesterol transport pathway for bile acid synthesis and for excretion as free cholesterol into the bile ${ }^{(52)}$.

All LDL compounds decreased in Chol-N rats, suggesting that fewer LDL is formed in those rats; moreover, VLDL composition suggests that VLDL of Chol-N is larger than those of Chol-K or Chol-C rats. According to Havel ${ }^{(53)}$, large VLDL contributes less to the formation of LDL than small VLDL in rats and other animals.

\section{Arylesterase activity}

$\mathrm{AE}$ is involved in lipoprotein metabolism and inhibits lipoperoxidation in LDL and HDL ${ }^{(54)}$. AE binds to HDL, but also to other lipoproteins ${ }^{(55)}$. AE activity increases in rats consuming pomegranate polyphenols ${ }^{(19)}$. The presence of antioxidants and other phytochemicals in Nori and Konbu( ${ }^{(5)}$ at least partially explains the greater absolute $\mathrm{AE}$ activity in NChol-N and NChol-K rats than that observed in NChol-C animals. The same effect or tendency was observed when data were adjusted for cholesterol, HDL cholesterol and HDL cholesterol mass.
AE activity decreased after the hypercholesterolaemic induction in all diets, but mainly in those containing algae. Hypercholesterolaemia may be associated with increased lipid peroxidation ${ }^{(56)}$. Low $\mathrm{AE}$ values in rats fed the Chol-C may be due to one or both of the following causes: (1) increased peroxidation ${ }^{(57)}$ and/or (2) increased hepatic uptake of HDL in the reverse cholesterol transport pathway, as AE is primarily bound to that molecule. However, the possible negative effect of some alga heavy metals (such as arsenic) on the AE activity should not be discarded because consumption of these algae has been found to negatively affect the glutathione system of the liver ${ }^{(5,7)}$, and arsenic has been found to increase oxidative stress and morbidity and mortality from $\mathrm{CVD}^{(45)}$.

In short, inclusion in the diet of $7 \%$ dried Nori or Konbu in the absence of cholesterol increased postprandial AE activity in growing Wistar rats. Konbu slightly but significantly increased postprandial lipoprotein concentrations in these rats. Postprandial levels of plasma cholesterol were lower in rats given cholesterol-enriched diets including Nori, suggesting that Nori is the alga of choice in dietary treatment of hypercholesterolaemia.

\section{Acknowledgements}

The present work was supported by the Spanish Ministerio de Investigación y Ciencia projects AGL-2005-07 204-C02-01/ ALI and AGL-2008 04 892-C03-02 and by Consolider-Ingenio 2010 project reference CSD2007-00 016.All authors have significantly contributed to the paper and agree with the present version of the manuscript. F. J. S.-M. is the corresponding author and Guarantor of the paper and has contributed to the study design, data discussion and writing of the paper. A. B. J. B. and S. B. have contributed to the data acquisition and analysis and writing of the paper, M. N. and J. M. S.-M. have contributed to arylesterase measurement, data analysis and writing of the paper. The rats were handled according to the Guide for the Care and Use of Laboratory Animals published by the National Research Council. The study was approved by the Spanish Science and Technology Advisory Committee and by an ethics committee of the Facultad de Farmacia of the Universidad Complutense de Madrid (Spain). The authors declare that there are not conflicts of interest.

\section{References}

1. Nisizawa K, Noda H, Kikuchi R, et al. (1987) The main seaweed foods in Japan. Hydrobiology 151/152, 5-29.

2. Mabeau S, Vallat O \& Brault D (1990) De L'Orient à L'Occident: les principaux marchés, le charme discret des macroalgues. Biofutur 3, 24-29.

3. Jiménez-Escrig A \& Goñi I (1999) Evaluación nutricional y efectos fisiológicos de macroalgas marinas comestibles. Arch Latinoam Nutr 49, 114-120.

4. McHuhh D (1991) Worldwide distribution of commercial resources of seaweeds including Gelidium. Hydrobiology 221, $19-29$.

5. Bocanegra A, Bastida S, Benedí J, et al. (2009) Review. Characteristics and nutritional and cardiovascular-health properties of seaweeds. J Med Food 12, 236-258. 
6. Jiménez-Escrig A \& Sánchez-Muniz FJ (2000) Dietary fibre from edible seaweeds: chemical structure physicochemical properties and effects on cholesterol metabolism. Nutr Res 20, 585-598.

7. Bocanegra A, Benedí J \& Sánchez-Muniz FJ (2006) Differential effects of konbu and nori seaweed dietary supplementation on liver glutathione status in normo- and hypercholesterolaemic growing rats. Br J Nutr 95, 696-702.

8. Castelli WP (1996) Lipids, risk factors and ischaemic heart disease. Atherosclerosis 124, 1-9.

9. Barter PJ \& Rye KA (1996) High density lipoproteins and coronary heart disease. Atherosclerosis 121, 1-12.

10. Alipour A, Elte JW, van Zaanen HC, et al. (2008) Novel aspects of postprandial lipaemia in relation to atherosclerosis. Atheroscler Suppl 9, 39-44.

11. Olson B \& Schneeman BO (1998) Alimentary lipaemia is enhanced in fiber-fed rats. J Nutr 128, 1031-1036.

12. Lairon D, Play B \& Jourdheuil-Rahmani D (2007) Digestible and indigestible carbohydrates: interactions with postprandial lipid metabolism. J Nutr Biochem 18, 217-227.

13. Ebihara K \& Schneeman BO (1989) Interaction of bile acids, phospholipids, cholesterol and triglyceride with dietary fibers in the small intestine of rats. J Nutr 119, 1100-1106.

14. Redard CL, Davis PA, Middleton SJ, et al. (1992) Postprandial lipid response following a high fat meal in rats adapted to dietary fiber. $J$ Nutr 122, 219-228.

15. Nus M, Sánchez-Muniz FJ, Sinisterra Gago JV, et al. (2008) Determination of rat and mice arylesterase activity using serum mimetics. Enzyme Microb Tech 43, 252-256.

16. Canales A \& Sánchez-Muniz FJ (2003) Paraoxonase, something more than an enzyme? Med Clin (Barc) 121, 537-548.

17. Gur M, Aslan M, Yildiz A, et al. (2006) Paraoxonase and arylesterase activities in coronary artery disease. Eur J Clin Invest 36, 779-787.

18. López-Oliva E, Nus M, Agis-Torres A, et al. (2009) Growth hormone improves lipoprotein concentration and arylesterase activity in mice with an atherogenic lipid profile induced by lactalbumin. Br J Nutr 101, 518-526.

19. Rock W, Rosenblat M, Miller-Lotan R, et al. (2008) Consumption of wonderful variety pomegranate juice and extract by diabetic patients increases paraoxonase 1 association with high-density lipoprotein and stimulates its catalytic activities. J Agric Food Chem 56, 8704-8713.

20. Rupérez P \& Saura-Calixto F (2001) Dietary fiber and physicochemical properties of edible Spanish seaweeds. Eur Food Res Technol 212, 349-354.

21. Colombo ML, Risè $\mathrm{P}$, Giavarini $\mathrm{F}$, et al. (2006) Marine macroalgae as sources of polyunsaturated fatty acids. Plant Foods Hum Nutr 61, 67-72.

22. Jeong BY, Cho DM, Moon SK, et al. (1993) Quality factors and functional components in the edible seaweeds. I. Distribution on $n-3$ fatty acids in 10 species of seaweeds by their habitats. J Korean Soc Food Nutr 22, 612-628.

23. Yoshie Y, Wang W, Petillo D, et al. (2000) Distribution of catechins in Japanese seaweeds. Fish Sci 66, 998-1000.

24. Nakamura T (1996) Antioxidant activity of phlorotannins isolated from the brown alga Eisenia bicyclis. Fish Sci 62 , 923-926.

25. Pavia H \& Aberg P (1996) Spatial variation in polyphenolic content of Ascophyllum nodosum (Fucales, Phaeophyta). Hydrobiology 326-327, 199-203.

26. National Research Council (NRC) (1996) Guide for the Care and Use of Laboratory Animals. Institute of Laboratory Animal Resources. Commission on Life Sciences. National Academy Press: Washington, DC.

27. Sánchez-Muniz FJ, García-Linares MC, García-Arias MT, et al. (2003) Fat and protein from olive oil-fried sardines interact to normalize serum lipoproteins and reduce liver lipids in hypercholesterolaemic rats. J Nutr 133, 2302-2308.

28. Terpstra AH, Woodward CJ \& Sanchez-Muniz FJ (1981) Improved techniques for the separation of serum lipoproteins by density gradient ultracentrifugation: visualization by prestaining and rapid separation of serum lipoproteins from small volumes of serum. Anal Biochem 111, 149-157.

29. Daher CF, Slaiby R, Haddad N, et al. (2006) Effect of acute and chronic moderate red or white wine consumption on fasted and postprandial lipemia in the rat. Toxicol Environ Health A 69 , $1117-1131$.

30. Terpstra AH (1985) Isolation of serum chylomicrons prior to density gradient ultracentrifugation of other serum lipoprotein classes. Anal Biochem 150, 221-227.

31. Lowry OH, Rosebrough NJ, Farr AL, et al. (1951) Protein measurement with the Folin-Phenol reagents. $J$ Biol Chem 193, 265-275.

32. Nus M, Sánchez-Muniz FJ \& Sánchez-Montero JM (2006) A new method for the determination of arylesterase activity in human serum using simulated body fluid. Atherosclerosis 188, 155-159.

33. Wong KH, Sam SW, Cheung PCK, et al. (1999) Changes in lipid profiles of rats fed with seaweed-based diets. Nutr Res 19, 1519-1527.

34. Vázquez J \& Sánchez-Muniz FJ (1994) Revisión: Proteínas de pescado y metabolismo del colesterol. Rev Esp Cien Tecnol Alim 34, 589-608.

35. Sanchez-Muniz FJ \& Bastida S (2008) Do not use the Friedewald formula to calculate LDL-cholesterol in hypercholesterolaemic rats. Eur J Lipid Sci Technol 110, 295-301.

36. Garrido-Polonio C, García-Linares MC, García-Arias MT, et al. (2004) Thermally oxidised sunflower-seed oil increases liver and serum peroxidation and modifies lipoprotein composition in rats. Br J Nutr 92, 257-265.

37. Hogarth CA, Roy A \& Ebert DL (2003) Genomic evidence for the absence of a functional cholesteryl ester transfer protein gene in mice and rats. Comparative Biochem Physiol B Biochem Mol Biol 135, 219-229.

38. Sigurdsson G, Nicoli A \& Lewis B (1975) Conversion of very low desnsity lipoprotein to low density lipoprotein. A metabolic study of apolipoprotein B kinetics in human subjects. J Clin Invest 56, 1481-1490.

39. Gueux E, Mazur A, Rayssiguier Y, et al. (1996) Lipid fluidity of triacylglycerol-rich lipoproteins insolated from copper-deficient rats. Br J Nutr 75, 767-773.

40. Bocanegra A, Nieto A, Blas B, et al. (2003) Diets containing a high percentage of Nori or Konbu algae are well-accepted and efficiently utilised by growing rats but induce different degrees of histological changes in the liver and bowel. Food Chem Toxicol 41, 1473-1480.

41. Gatti E, Catenazzo G, Camisasca E, et al. (1984) Effects of guar-enriched pasta in the treatment of diabetes and hyperlipidemia. Ann Nutr Metab 28, 1-10.

42. Cara L, Dubois C, Borel P, et al. (1992) Effects of oat bran, rice bran, wheat fiber, and wheat germ on postprandial lipaemia in healthy adults. Am J Clin Nutr 55, 81-88.

43. Dubois C, Armand M, Senft M, et al. (1996) Chronic oat bran intake alters postprandial lipaemia and lipoproteins in healthy adults. Am J Clin Nutr 61, 325-333.

44. Schneeman BO, Kotite L, Todd KM, et al. (1993) Relationships between the responses of triglyceride-rich lipoproteins in blood plasma containing apolipoproteins B-48 and B-100 to a fat-containing meal in normolipidemic humans. Proc Natl Acad Sci U S A 90, 2069-2073.

45. States JC, Srivastava S, Chen Y, et al. (2009) Arsenic and cardiovascular disease. Toxicol Sci 107, 312-323.

46. Klevay LM (1975) Coronary heart disease: the zinc/copper hypothesis. Am J Clin Nutr 28, 764-770. 
47. Jacques H (1990) Effects of dietary fish proteins on plasma cholesterol and lipoproteins in animal models and in humans. Dietary Proteins, Cholesterol Metabolism and Atherosclerosis, pp. 59-70 [M Sugano and AC Beynen, editors]. Switzerland: Karger Basel.

48. Chiang MT, Chen YC \& Huang AL (1998) Plasma lipoprotein cholesterol levels in rats fed a diet enriched in cholesterol and cholic acid. Int J Vitam Nutr Res 68, 328-334.

49. Bocanegra A, Nieto A, Bastida S, et al. (2008) A Nori but not a Konbu, dietary supplement decreases the cholesterolaemia, liver fat infiltration and mineral bioavailability in hypercholesterolaemic growing Wistar rats. Br J Nutr 99, 272-280.

50. Terpstra AH \& Beynen AC (1984) Density profile and cholesterol concentration of serum lipoproteins in experimental animals and human subjects on hypercholesterolaemic diets. Comp Biochem Physiol B 77, 523-528.

51. Loison C, Mendy F, Serougne C, et al. (2002) Dietary myristic acid modifies the HDL-cholesterol concentration and liver scavenger receptor BI expression in the hamster. Br J Nutr 87, 199-210.
52. Bothan KM \& Bravo E (1995) The role of lipoprotein in biliary steroid secretion. Studies with in vivo experimental models. Prog Lipid Res 34, 71-97.

53. Havel RJ (1984) The formation of LDL: mechanisms and regulation. J Lipid Res 25, 1570-1576, www.jlr.org at 26961547 (accessed 20 May 2009).

54. Aviram M (2004) Serial review: paraoxonases. Introduction to the serial review on Paraoxonases, oxidative stress, and cardiovascular diseases. Free Radic Biol Med 37, 1301-1303.

55. Fuhrman B, Volkova N \& Aviram M (2005) Paraoxonase 1 (PON1) is present in postprandial chylomicrons. Atherosclerosis 180, 55-61.

56. Reilly MP, Pratico D, Delanty N, et al. (1998) Increased formation of distinct F2 isoprostanes in hypercholesterolaemia. Circulation 98, 2785-2787.

57. Bhattacharyya T, Nicholls SJ, Topol EJ, et al. (2008) Relationship of paraoxonase 1 (PON1) gene polymorphisms and functional activity with systemic oxidative stress and cardiovascular risk. JAMA 299, 1265-1276. 